\title{
Effect of preoperative pneumococcal immunization on the incidence of respiratory infection in the postoperative period of cardiac surgery
}

\author{
Efeito da imunização pneumocócica pré-operatória na incidência de infecção respiratória no pós- \\ operatório de cirurgia cardíaca
}

Efecto de la inmunización neumocócica preoperatoria sobre la incidencia de la infección respiratoria en el postoperatorio de la cirugía cardíaca

Received: 03/17/2021 | Reviewed: 03/23/2021 | Accept: 03/24/2021 | Published: 04/02/2021

\author{
Stéfani Galli \\ ORCID: https://orcid.org/0000-0002-1453-7680 \\ Universidade Estadual de Ponta Grossa, Brazil \\ E-mail: stefanigalli@hotmail.com \\ Mário Augusto Cray da Costa \\ ORCID: https://orcid.org/0000-0001-9377-9495 \\ Universidade Estadual de Ponta Grossa, Brazil \\ E-mail:drmarioaugusto@uol.com.br \\ Ana Carolina Mello Fontoura de Souza \\ ORCID: https://orcid.org/0000-0003-2324-1301 \\ Universidade Estadual de Ponta Grossa, Brazil \\ E-mail: acmfs00@gmail.com \\ Dionizia Xavier Scomparin \\ ORCID: https://orcid.org/0000-0001-8658-2467 \\ Universidade Estadual de Ponta Grossa, Brazil \\ E-mail: scomparindio@hotmail.com
}

\begin{abstract}
Objective: To analyze whether the incidence of respiratory infections in the postoperative period of cardiac surgery is lower in patients immunized with the 13-valent pneumococcal conjugate vaccine. To study the main risk factors related to the development of infections in patients undergoing cardiac surgery. Methodology: 40 patients were included in the study, randomized 1: 1 to receive pneumococcal vaccine or placebo, 14 days before undergoing elective cardiac surgery. The incidence of infections in the 30 postoperative days was compared between groups. Results: There were 6 respiratory infections in the vaccine group and 2 in the placebo group $(\mathrm{p}=0.2024)$ and one death in the placebo group and none in the vaccine group $(\mathrm{p}=0.3173)$. Chronic obstructive pulmonary disease $(\mathrm{p}=0.003)$, diabetes mellitus $(\mathrm{p}=0.047)$ and peripheral arterial disease $(\mathrm{p}=0.0001)$ were listed as risk factors for the development of infections, which generated an increase in hospital stay $(95 \% \mathrm{CI}: 1.33-7.13 ; \mathrm{p}=0.0147)$ and ICU stay in the postoperative period (95\% CI: $1.87-33.45$; $\mathrm{p}=0.0025)$. Conclusion: The application of pneumococcal vaccine $13 \mathrm{v}$ did not influence the development of postoperative pulmonary infections. Chronic obstructive pulmonary disease, diabetes mellitus and peripheral arterial disease were identified as risk factors for the development of infections, increasing the length of total hospital stay and time in the ICU.
\end{abstract}

Keywords: Pneumonia; Thoracic surgery; Pneumococcal pneumonia; Immunization; Pneumococcal vaccines.

\section{Resumo}

Objetivo: Analisar se a incidência de infecções respiratórias no pós-operatório de cirurgias cardíacas é menor em pacientes imunizados com a vacina pneumocócica conjugada 13- valente. Estudar quais os principais fatores de risco relacionados ao desenvolvimento de infecções nos pacientes submetidos a cirurgia cardíaca. Metodologia: Foram incluídos no estudo 40 pacientes, randomizados 1:1 para receber vacina pneumocócica ou placebo, 14 dias antes de serem submetidos a cirurgia cardíaca eletiva. A incidência de infecções nos 30 dias de pós-operatório foi comparada entre os grupos através de cálculos de média, mediana e risco relativo, pelos testes T de Student, Mann-Whitney, Fischer e Qui-quadrado. Resultados: Ocorreram 6 infecções respiratórias no grupo vacina e 2 no grupo placebo (p= $0,2024)$ e um óbito no grupo placebo e nenhum no grupo vacina $(\mathrm{p}=0,3173)$. Doença pulmonar obstrutiva crônica $(\mathrm{p}=0,003)$, diabetes mellitus $(\mathrm{p}=0,047)$ e doença arterial periférica $(\mathrm{p}=0,0001)$ foram relacionados como fatores de risco para desenvolvimento de infecções, que geraram aumento do tempo de internação (95\% IC: 1,33- 7,13; $\mathrm{p}=0,0147$ ) e permanência em UTI no pós-operatório (95\% IC: 1,87- 33,45; p= 0,0025). Conclusão: A aplicação da vacina pneumocócica 13v não influenciou no desenvolvimento de infecções pulmonares pós-operatórias. Doença pulmonar obstrutiva crônica, diabetes mellitus e doença arterial periférica foram apontadas como fator de risco para 
o desenvolvimento de infecções, aumentando o tempo de internamento total e tempo em UTI.

Palavras-chave: Pneumonia; Cirurgia torácica; Pneumonia pneumocócica; Imunização; Vacinas pneumocócicas.

\section{Resumen}

Objetivo: Analizar si la incidencia de infecciones respiratorias tras la cirugía cardíaca es menor en los pacientes inmunizados con la vacuna neumocócica conjugada 13-valente. Estudiar los principales factores de riesgo relacionados con el desarrollo de infecciones en pacientes sometidos a cirugía cardíaca. Metodología: Se incluyeron en el estudio 40 pacientes, aleatorizados 1:1 para recibir la vacuna neumocócica o un placebo, 14 días antes de someterse a una cirugía cardíaca electiva. La incidencia de infecciones en los 30 días postoperatorios se comparó entre los grupos mediante el cálculo de la media, la mediana y el riesgo relativo, a través de las pruebas T de Student, Mann-Whitney, Fischer y Chi-cuadrado. Resultados: Se produjeron seis infecciones respiratorias en el grupo de la vacuna y dos en el grupo del placebo $(\mathrm{p}=0,2024)$ y una muerte en el grupo del placebo y ninguna en el grupo de la vacuna $(\mathrm{p}=0,3173)$. La enfermedad pulmonar obstructiva crónica $(\mathrm{p}=0,003)$, la diabetes mellitus $(\mathrm{p}=0,047)$ y la enfermedad arterial periférica $(\mathrm{p}=0,0001)$ se relacionaron como factores de riesgo para desarrollar infecciones, lo que generó un aumento de la duración de la estancia (IC 95\%: 1,33- 7,13; p=0,0147) y de la estancia postoperatoria en la UCI (IC 95\%: 1,87- 33,45; p= 0,0025). Conclusión: La aplicación de la vacuna neumocócica 13v no influyó en el desarrollo de infecciones pulmonares postoperatorias. La enfermedad pulmonar obstructiva crónica, la diabetes mellitus y la enfermedad arterial periférica fueron consideradas como factores de riesgo para el desarrollo de infecciones, aumentando el tiempo de internamiento total y el tiempo de IU.

Palabras clave: Neumonía; Cirugía torácica; Neumonía neumocócica; Inmunización; Vacunas neumocócicas.

\section{Introduction}

Cardiovascular diseases (CVD) are the main causes of death in the world, with the greatest impact in low and middle income countries, according to Lentsck, Latorre and Mathias (2015). In Brazil, in 2016, these diseases were the cause of death for more than 360 thousand people, predominantly male, white and over 65 years old (Ministry of Health , 2019). In many cases, the treatment of such diseases is done through surgical interventions, very common in Brazil, where approximately 102 thousand operations are performed annually (Dordetto; Pinto \& Rosa, 2016).

The main complication of cardiac surgery is infection, of which pneumonia stands out, adding complexity to the treatment of the patient, increasing hospitalization costs, hospitalization time and mortality rates (Vera Urquiza, Bucio Reta, Berríos Bárcenas \& Choreño Machain, 2016; Damavandi, Javan, Moshashaei, Forootan \& Darvishi, 2020). Among the main etiologic agents of pneumonia, whether hospitalized or acquired in the community, is Streptococcus pneumoniae, a lanceolate diplococcus, which causes not only pneumonias, but also meningitis, septic arthritis, pleurisy and endocarditis (Bonten et al, 2015).

However, there are various pneumococcal vaccines available, among them the pneumococcal conjugate vaccine 13valent, which prevents about $90 \%$ of the diseases caused by 13 different serotypes of pneumococci (SBIM, 2020).

Based on this scenario, this study aimed to study whether the application of this vaccine 14 days before elective cardiac surgery would decrease the incidence of postoperative infections, including pneumonia. Studies using 13-v conjugated pneumococcal immunization for this purpose have not yet been published, which motivated this research.

In addition, the objective was to assess the impact of vaccination on the number of deaths, length of hospital stay and in the intensive care unit and to study the main epidemiological, clinical, intraoperative and postoperative risk factors related to the development of infections in the postoperative period of cardiac surgeries. It also seeks to attract the attention of researchers, professionals and health managers to the theme, inspiring new multidisciplinary research in the field of infection prevention. 


\section{Methodology}

\subsection{Type of Study}

This is a randomized clinical trial (Pereira et al, 2018) conducted from January to December 2020. The study was conducted with 40 patients undergoing cardiac surgery at Hospital Angelina Caron in Campina Grande do Sul/PR and at Santa Casa de Misericórdia in Ponta Grossa/ PR. All were informed about the nature of the research and signed the Free and Informed Consent Form in accordance with resolution 466/2012 of the National Health Council of the Ministry of Health. This project was approved by the Research Ethics Committee of the State University of Ponta Grossa, opinion number 3.591.156.

\subsection{Inclusion and Exclusion Criteria}

The inclusion criteria were: male and female patients candidates for elective cardiac surgery, who signed the Free and Informed Consent Form (ICF), older than 50 years, who were not immunized with any dose of pneumococcal conjugate vaccine during their lifetime.

The exclusion criteria were: emergency or urgent surgery in which there was no possibility of pre-vaccination.

Sampling was carried out for convenience and depended on availability for placebo/vaccine application 14 days before surgery.

\subsection{Groups}

The 40 patients were randomized 1: 1 to receive immunization with the $13 \mathrm{v}$ pneumococcal conjugate vaccine (PREVENAR 13) manufactured by the Pfizer laboratory or the placebo $(0.5 \mathrm{ml}$ of physiological saline). All of them signed the Free and Informed Consent Form (ICF).

During the outpatient visit for scheduling the surgery, 14 days before the procedure, we obtained ICFs and collected registration data of patients, as well as the clinical variables and the complementary preoperative exams mentioned below. Then, the vaccine or placebo was administered as a single dose, intramuscularly, in the deltoid muscle. The patients were followed until discharge and outpatient for 30 days postoperatively. The intraoperative and postoperative variables mentioned below were prospectively collected.

\subsection{Studied Variables}

a) Age, divided into (i) patients aged 65 or under, (ii) patients aged over 65;

b) Gender;

c) Weight;

d) Height;

e) Creatinine;

f) Renal dysfunction divided into four groups: (i) renal function considered normal when the creatinine clearance (CC) is greater than $85 \mathrm{~mL} / \mathrm{min}$, (ii) considered moderate when the $\mathrm{CC}$ is in the interval between $85 \mathrm{~mL} / \mathrm{min}$ and $50 \mathrm{ml} / \mathrm{min}$, (iii) severe dysfunction with the lowest DC $50 \mathrm{ml} / \mathrm{min}$, and (iv) patients are on dialysis (Nashef et al., 2012);

g) Diabetes: divided into patients (i) with diabetes mellitus and (ii) without a diagnosis of diabetes mellitus, including prediabetic patients (Nashef et al., 2012);

h) Use of insulin;

i) Peripheral arterial disease, patients with peripheral arterial disease were considered to have (i) carotid lesion greater than $50 \%$, (ii) claudication, (iii) limb amputation due to arterial disease, (iv) procedure performed or planned correction of abdominal aortic aneurysm, lower limb revascularization or carotid stenosis (Nashef et al., 2012); 
j) Previous cardiac surgery, defined as one or more procedures that involved opening the pericardium (Nashef et al., 2012);

k) Chronic obstructive pulmonary disease, defined by the chronic use of bronchodilators or corticosteroids;

1) Functional class by the New York Heart Association (NYHA): divided into (i) asymptomatic patients, (ii) symptomatic patients at medium effort, (iii) symptomatic patients at small effort, and (iv) patients with symptoms at rest (Nashef et al., 2012);

m) Presence of unstable angina, defined as the inability to perform any activities without symptoms or with angina at rest (Nashef et al., 2012);

n) Ejection fraction assessed by echocardiogram using the Teicholz or Simpson methods (for cases with altered segmental contractility);

o) Presence of recent acute myocardial infarction (AMI) ( $<90$ days after the procedure) (Nashef et al., 2012);

p) Pulmonary hypertension, classified as moderate when the pulmonary artery systolic pressure was between 31 and $55 \mathrm{mmHg}$ and severe when greater than $55 \mathrm{mmHg}$ (Nashef et al., 2012);

q) Type of procedure performed, divided into (i) coronary, (ii) valvular, (iii) coronary and valvular and (iv) others. Due to the need to apply pneumococcal vaccine 14 days before the procedure, urgent procedures were not performed in this study, only elective procedures;

r) Need or not to approach the thoracic aorta;

s) EuroSCORE II, classified as: (i) low risk when the values are below 2, (ii) medium risk, when they are between 2 and 4, (iii) high risk, when they are between 4 and 6 and (iv) very high risk, when above 6. The EuroSCORE was calculated from the variables collected above, since it considers as variables for the calculation: (i) age; (ii) gender; (iii) creatinine clearance; (iv) peripheral arterial disease; (v) reduced mobility; (vi) previous cardiac surgery; (vii) chronic lung disease; (viii) endocarditis; (ix) critical preoperative state; (x) diabetes and use of insulin; (xi) NYHA functional class; (xii) unstable angina; (xiii) left ventricular function; (xiv) recent acute myocardial infarction; (xv) pulmonary hypertension; (xvi) type of intervention; (xvii) urgency of the procedure and (xviii) thoracic aorta surgery (Nashef et al., 2012);

t) Cardiopulmonary bypass time;

u) Aortic clamping time;

v) ICU stay time, divided into (i) four days or less, (ii) more than four days;

w) Post-operative hospital stay, divided into (i) five days or less, (ii) more than five days;

x) Presence of infection, divided into (i) patients who had no infection, (ii) pulmonary infections, (iii) another infection;

y) Death, divided into (i) patient who was discharged; (ii) death during hospitalization; (iii) death after discharge;

z) Depression or anxiety;

aa) Hypothyroidism;

bb) Systemic arterial hypertension;

cc) Dyslipidemia, divided into (i) patients without dyslipidemia, (ii) high LDL, (iii) low HDL, (iv) high triglycerides, (v) mixed dyslipidemia;

dd) Smoking, divided into (i) smoker, (ii) non-smoker, (iii) ex -smoker;

ee) Alcoholism, divided into (i) alcoholic, (ii) non-alcoholic, (iii) ex-alcoholic.

\subsection{Statistical Analysis}

Initially, a descriptive analysis of the data was carried out with an estimate of simple (n) and relative (\%) frequency in general and in the vaccine and placebo groups. Categorical variables were compared using the Fischer and Chisquare tests. Continuous variables were tested for normality by the Kolmogorov-Smirnov test. When there was normal 
distribution they were presented as mean and tested by the Student's T Test and when not normal they were presented as medians and analyzed using the Mann-Whitney test. It was considered significant when $\mathrm{p}<0.05$.

The relative risks of the outcomes were calculated: discharge/death and presence/absence of lung infection or other infections. For better visualization of the results, graphs were produced. The same variables were also analyzed by comparing values between groups of patients who had infections and those who did not develop them. The relative risk of the exposed group (vaccine) was also calculated compared to the unexposed group (placebo) according to the presence/absence of each outcome. The same was done for patients who had or did not have postoperative infections. The analysis were performed using the MedCalc ${ }^{\circledR}$ software 19.6.4.

\section{Results}

Twenty patients were included in the vaccine group and 20 in the placebo group, these groups being homogeneous with respect to the pre and intraoperative variables studied, except for the aortic clamping time, which was higher in the vaccine group 71.5 versus 58.5 minutes $(\mathrm{p}=0.0184)$, as shown in Table 1 .

The studied patients were between 48 and 82 years old, with a mean of 64.2 years, with $45 \%$ of the patients being over 65 . Most of the participants were male $(82.5 \%)$, the mean weight of the patients was $75.67 \mathrm{~kg}$ and the mean height was $1.67 \mathrm{~m}$. The median creatinine was 1 , being 1.01 for the vaccine group and 0.975 for the placebo group.

Regarding the presence of renal dysfunction, 16 patients had no dysfunction, while 20 had moderate dysfunction and none was on dialysis. The majority, $70 \%$ (28) of the patients did not have a diagnosis of diabetes mellitus. Of the $12 \mathrm{DM}$ patients, six were in the vaccine group and of the 28 who did not have DM, 14 were in the vaccine group. Only two (5\%) used insulin.

Six patients (15\%), in turn, had chronic obstructive pulmonary disease, with 4 in the vaccine group. The majority $(87.5 \%)$ of the patients did not have peripheral arterial disease, except for five who had carotid lesions, of which 4 were in the vaccine group. The prevalence of other co-morbidities are described in Table 1.

The main procedures performed were coronary (35\%) and valvular (50\%), while $10 \%$ of the sample underwent both simultaneously and only 5\% underwent another class of surgery, namely a left ventricular aneurysmectomy and a correction of atrial septal defect (Graph 1). Only 2 patients (5\%) underwent approach to the thoracic aorta and 5 (12.5\%) had previous heart surgery. There was only one death in a patient belonging to the placebo group, due to a non-infectious cause, which also occurred during hospitalization. 
Graph 1 - Relative frequency of the procedures to which the patients were submitted.

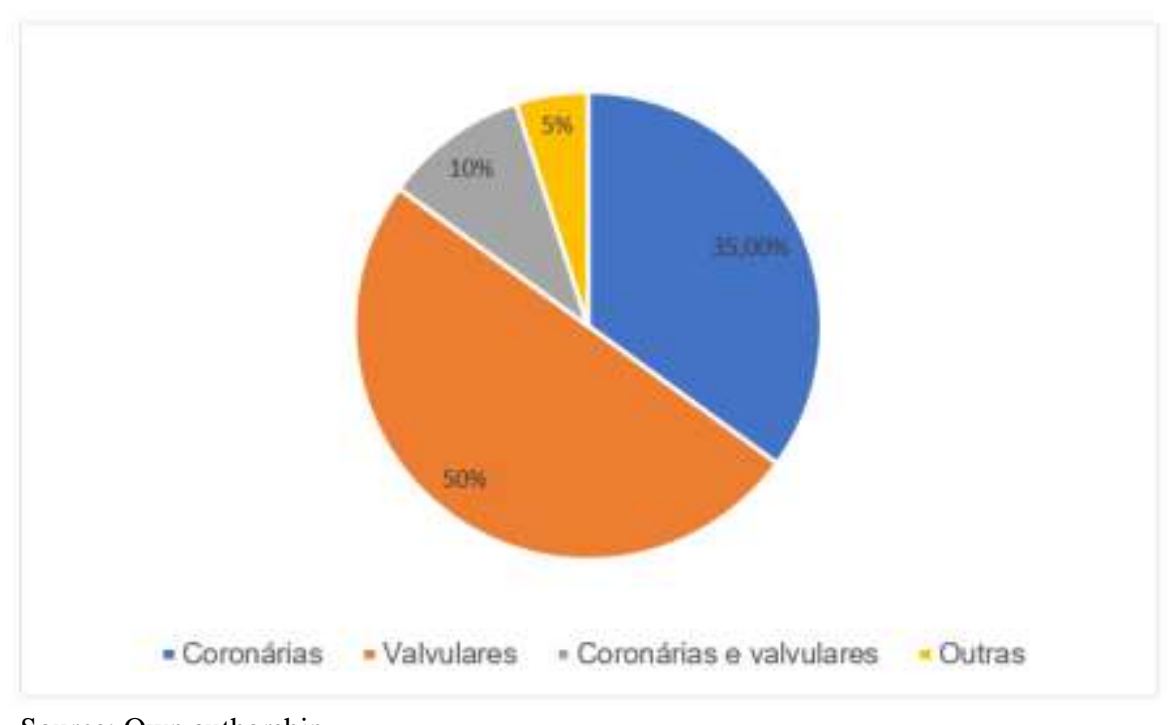

Source: Own authorship.

The participants' ejection fraction, the presence of recent acute myocardial infarction or pulmonary hypertension were also studied. According to the functional class of the New York Heart Association (NYHA), most were in class I or II. All the variables mentioned were then grouped and the EuroSCORE II of each patient was calculated, with the majority $(55 \%)$ being in the low risk class (Table 1$)$.

Table 1 - Absolute and relative frequency of each variable according to the vaccine and placebo groups.

\begin{tabular}{|c|c|c|c|c|}
\hline Variable & Categories & Vaccine & Placebo & Total \\
\hline Age & $\begin{array}{l}\leq 65 \text { years } \\
>65 \text { years }\end{array}$ & $\begin{array}{l}11(50 \%) \\
9(50 \%)\end{array}$ & $\begin{array}{l}11(50 \%) \\
9(50 \%)\end{array}$ & $\begin{array}{l}22(55 \%) \\
18(45 \%) \\
\mathrm{P}=0.6244 *\end{array}$ \\
\hline Gender & $\begin{array}{l}\text { Male } \\
\text { Female }\end{array}$ & $\begin{array}{l}17(51.5 \%) \\
3(42.8 \%)\end{array}$ & $\begin{array}{l}16(48.4 \%) \\
4(57.1 \%)\end{array}$ & $\begin{array}{l}33(82.5 \%) \\
7(17.5 \%) \\
P=0.5 *\end{array}$ \\
\hline Mean Weight & - & $78.75 \mathrm{~kg}$ & $72.6 \mathrm{~kg}$ & $\begin{array}{l}75.67 \mathrm{~kg} \\
\mathrm{P}=0.2171 * * * *\end{array}$ \\
\hline Mean Height & - & $1.67 \mathrm{~m}$ & $1.66 \mathrm{~m}$ & $\begin{array}{l}1.67 \mathrm{~m} \\
\mathrm{P}=0.7761 * * * *\end{array}$ \\
\hline Median Creatinine & - & 1.01 & 0.9750 & $\begin{array}{l}1.00 \\
\mathrm{P}=0.7454 * * *\end{array}$ \\
\hline Renal Dysfunction & $\begin{array}{l}\text { No dysfunction } \\
\text { Moderate } \\
\text { Severe } \\
\text { Dialysis }\end{array}$ & $\begin{array}{l}8(50 \%) \\
11(55 \%) \\
1(25 \%) \\
0(0 \%)\end{array}$ & $\begin{array}{l}8(50 \%) \\
9(45 \%) \\
3(75 \%) \\
0(0 \%)\end{array}$ & $\begin{array}{l}16(40 \%) \\
20(50 \%) \\
4(10 \%) \\
0(0 \%) \\
\mathrm{P}=0.5488 * *\end{array}$ \\
\hline Diabetes & $\begin{array}{l}\text { With DM } \\
\text { Without DM }\end{array}$ & $\begin{array}{l}6(50 \%) \\
14(50 \%)\end{array}$ & $\begin{array}{l}6(50 \%) \\
14(50 \%)\end{array}$ & $\begin{array}{l}12(30 \%) \\
28(70 \%) \\
\mathrm{P}=0.6344 *\end{array}$ \\
\hline Insulin use & $\begin{array}{l}\text { Yes } \\
\text { No }\end{array}$ & $\begin{array}{l}2(50 \%) \\
18(50 \%)\end{array}$ & $\begin{array}{l}2(50 \%) \\
18(50 \%)\end{array}$ & $\begin{array}{l}4(10 \%) \\
36(90 \%) \\
P=0.6975 *\end{array}$ \\
\hline Peripheral Arterial Disease & $\begin{array}{l}\text { No } \\
\text { Carotids } \\
\text { Claudication } \\
\text { Abdominal Aortic } \\
\text { aneurysm }\end{array}$ & $\begin{array}{l}16(45.7 \%) \\
4(80 \%) \\
0(0 \%) \\
0(0 \%)\end{array}$ & $\begin{array}{l}19(54.3 \%) \\
1(20 \%) \\
0(0 \%) \\
0(0 \%)\end{array}$ & $\begin{array}{l}35(87.5 \%) \\
5(12.5 \%) \\
0(0 \%) \\
0(0 \%)\end{array}$ \\
\hline
\end{tabular}


Research, Society and Development, v. 10, n. 4, e11410413982, 2021

(CC BY 4.0) | ISSN 2525-3409 | DOI: http://dx.doi.org/10.33448/rsd-v10i4.13982

\begin{tabular}{|c|c|c|c|c|}
\hline & & & & $\mathrm{P}=0.1567 * *$ \\
\hline \multirow[t]{3}{*}{ Previous cardiac surgery } & Yes & $4(80 \%)$ & $1(20 \%)$ & $5(12.5 \%)$ \\
\hline & No & $16(45.7 \%)$ & $19(54.3 \%)$ & $35(87.5 \%)$ \\
\hline & & & & $\mathrm{P}=0.1708 *$ \\
\hline Chronic Obstructive & Yes & $4(66.6 \%)$ & $2(33.3 \%)$ & $6(15 \%)$ \\
\hline \multirow[t]{2}{*}{ Pulmonary Disease } & No & $16(47 \%)$ & $18(53 \%)$ & $34(85 \%)$ \\
\hline & & & & $\mathrm{P}=0.3307 *$ \\
\hline \multirow[t]{5}{*}{ NYHA Functional Class } & I & $3(42.8 \%)$ & $4(57.2 \%)$ & $7(17.5 \%)$ \\
\hline & II & $9(56.3 \%)$ & $7(43.7 \%)$ & $16(40 \%)$ \\
\hline & III & $7(63.6 \%)$ & $4(36.4 \%)$ & $11(27.5 \%)$ \\
\hline & IV & $1(16.7 \%)$ & $5(8.3 \%)$ & $6(15 \%)$ \\
\hline & & & & $\mathrm{P}=0.2750 * *$ \\
\hline \multirow[t]{3}{*}{ Unstable Angina } & No & $18(58 \%)$ & $13(42 \%)$ & $31(77.5 \%)$ \\
\hline & Yes & $2(2.2 \%)$ & $7(7.8 \%)$ & $9(22.5 \%)$ \\
\hline & & & & $\mathrm{P}=0.0636 *$ \\
\hline \multirow[t]{2}{*}{ Mean Ejection Fraction } & & 60.35 & 54.0 & 57.17 \\
\hline & - & & & $\mathrm{P}=0.1851 * * * *$ \\
\hline \multirow[t]{3}{*}{ Recent AMI } & Yes & $1(16.7 \%)$ & $5(83.3 \%)$ & $6(15 \%)$ \\
\hline & No & $19(55.9 \%)$ & $15(44.1 \%)$ & $34(85 \%)$ \\
\hline & & & & $\mathrm{P}=0.0908 *$ \\
\hline \multirow[t]{4}{*}{ Pulmonary hypertension } & Normal & $11(39.3 \%)$ & $17(60.7 \%)$ & $28(70 \%)$ \\
\hline & Moderate & $4(66.7 \%)$ & $2(33.3 \%)$ & $6(15 \%)$ \\
\hline & Severe & $5(83.3 \%)$ & $1(16.7 \%)$ & $6(15 \%)$ \\
\hline & & & & $\mathrm{P}=0.0993 * *$ \\
\hline \multirow[t]{5}{*}{ Surgery } & Coronary & $5(35.7 \%)$ & $9(64.3 \%)$ & $14(35 \%)$ \\
\hline & Valve & $12(60 \%)$ & $8(40 \%)$ & $20(50 \%)$ \\
\hline & Coronary and valve & $3(75 \%)$ & $1(25 \%)$ & $4(10 \%)$ \\
\hline & Other & $0(0 \%)$ & $2(100 \%)$ & $2(5 \%)$ \\
\hline & & & & $\mathrm{P}=0.1760 * *$ \\
\hline \multirow[t]{3}{*}{ Aortic Surgery } & Yes & $1(50 \%)$ & $1(50 \%)$ & $2(5 \%)$ \\
\hline & No & $19(50 \%)$ & $19(50 \%)$ & $38(95 \%)$ \\
\hline & & & & $\mathrm{P}=0.7564 *$ \\
\hline \multirow[t]{5}{*}{ EuroSCORE II } & Low risk $(<2)$ & $11(50 \%)$ & $11(50 \%)$ & $22(55 \%)$ \\
\hline & Medium risk (2-4) & $3(50 \%)$ & $3(50 \%)$ & $6(15 \%)$ \\
\hline & High risk (4-6) & $2(40 \%)$ & $3(60 \%)$ & $5(12.5 \%)$ \\
\hline & Very high risk $(>6)$ & $4(57.1 \%)$ & $3(42.9 \%)$ & $7(17.5 \%)$ \\
\hline & & & & $\mathrm{P}=0.9518 * *$ \\
\hline \multirow{2}{*}{$\begin{array}{l}\text { Median Cardiopulmonary } \\
\text { Bypass Time }\end{array}$} & - & 86.5 & 72 & 74.5 \\
\hline & - & & & $\mathrm{P}=0.1436 * * *$ \\
\hline \multirow[t]{2}{*}{ Median Aortic Clamping Time } & - & 71.5 & 58.5 & 63.5 \\
\hline & - & & & $\mathrm{P}=0.0184 * * *$ \\
\hline \multirow[t]{3}{*}{ Intensive Care Unit Time } & $\leq 4$ days & $15(46.9 \%)$ & $17(53.1 \%)$ & $32(80 \%)$ \\
\hline & $>4$ days & $5(62.5 \%)$ & $3(37.5 \%)$ & $8(20 \%)$ \\
\hline & & & & $\mathrm{P}=0.3473 *$ \\
\hline \multirow[t]{3}{*}{ Postoperative length of stay } & $\leq 5$ days & $12(44.4 \%)$ & $15(55.6 \%)$ & $27(67.5 \%)$ \\
\hline & $>5$ days & $8(61.5 \%)$ & $5(38.5 \%)$ & $13(32.5 \%)$ \\
\hline & & & & $\mathrm{P}=0.2503 *$ \\
\hline \multirow[t]{4}{*}{ Infection } & No & $12(41.4 \%)$ & $17(58.6 \%)$ & $29(72.5 \%)$ \\
\hline & Pulmonary & $6(75 \%)$ & $2(25 \%)$ & $8(20 \%)$ \\
\hline & Other & $2(66.7 \%)$ & $1(33.3 \%)$ & $3(7.5 \%)$ \\
\hline & & & & $\mathrm{P}=0.2024 * *$ \\
\hline \multirow[t]{4}{*}{ Death } & Discharge & $20(51.3 \%)$ & $19(48.7 \%)$ & $39(97.5 \%)$ \\
\hline & Death & $0(0 \%)$ & $1(100 \%)$ & $1(2.5 \%)$ \\
\hline & Death after discharge & $0(0 \%)$ & $0(0 \%)$ & $0(0 \%)$ \\
\hline & & & & $\mathrm{P}=0.3173 * *$ \\
\hline \multirow[t]{3}{*}{ Depression or Anxiety } & Yes & $8(61.5 \%)$ & $5(38.5 \%)$ & $13(32.5 \%)$ \\
\hline & No & $12(44.4 \%)$ & $15(55.6 \%)$ & $27(67.5 \%)$ \\
\hline & & & & $\mathrm{P}=0.2503 *$ \\
\hline Hypothyroidism & Yes & $4(100 \%)$ & $0(0 \%)$ & $4(10 \%)$ \\
\hline & No & $16(44.4 \%)$ & $20(55.6 \%)$ & $36(90 \%)$ \\
\hline
\end{tabular}


Research, Society and Development, v. 10, n. 4, e11410413982, 2021

(CC BY 4.0) | ISSN 2525-3409 | DOI: http://dx.doi.org/10.33448/rsd-v10i4.13982

\begin{tabular}{lllll}
\hline & & & $\mathrm{P}=0.053 *$ \\
\hline $\begin{array}{l}\text { Systemic Arterial } \\
\text { Hypertension }\end{array}$ & Yes & $17(53.1 \%)$ & $15(46.9 \%)$ & $\begin{array}{l}32(80 \%) \\
8(20 \%) \\
\end{array}$ \\
& No & $3(37.5 \%)$ & $5(62.5 \%)$ & $\mathrm{P}=0.3473 *$ \\
\hline Dyslipidemia & No & $3(50 \%)$ & $3(50 \%)$ & $6(17.6 \%)$ \\
& High LDL & $11(61.1 \%)$ & $7(38.9 \%)$ & $18(52.9 \%)$ \\
& Low HDL & $0(0 \%)$ & $1(100 \%)$ & $1(2.9 \%)$ \\
& Mixed & $3(42.9 \%)$ & $4(57.1 \%)$ & $7(20.6 \%)$ \\
& & & $\mathrm{P}=0.6054 * *$ \\
\hline Smoking & Yes & $7(70 \%)$ & $3(30 \%)$ & $10(25 \%)$ \\
& No & $6(37.5 \%)$ & $10(62.5 \%)$ & $16(40 \%)$ \\
& Ex-smoker & $7(50 \%)$ & $7(50 \%)$ & $14(35 \%)$ \\
& & & $\mathrm{P}=0.4645 * *$ \\
\hline Alcoholism & Yes & $2(40 \%)$ & $3(60 \%)$ & $5(12.5 \%)$ \\
& No & $14(46.7 \%)$ & $16(53.3 \%)$ & $30(75 \%)$ \\
& Ex-alcoholic & $4(80 \%)$ & $1(20 \%)$ & $5(12.5 \%)$ \\
& & & $\mathrm{P}=0.3442 * *$ \\
\hline
\end{tabular}

* Fischer test

** Chi Test - Square

*** Mann-Whitney test

**** Student's T Test

Source: Own authorship.

Finally, when studying the prevalence of infections, 29 (72.5\%) of the patients had no infections, of which 12 belonged to the vaccine group and 17 to the placebo group. Eight (20\%) had pulmonary infections, six of them in the vaccine group. There were also three patients (7.5\%) who had another type of infection, namely cholecystitis, sternal wound infection and sepsis. Of these three, two were part of the vaccine group. However, there was no statistical significance in the correlation between vaccine and infection $(\mathrm{p}=0.2024)$. These data were summarized in Graph 2.

Graph 2 - Absolute frequency of the number of deaths, pulmonary infections and other infections in the placebo and vaccine group

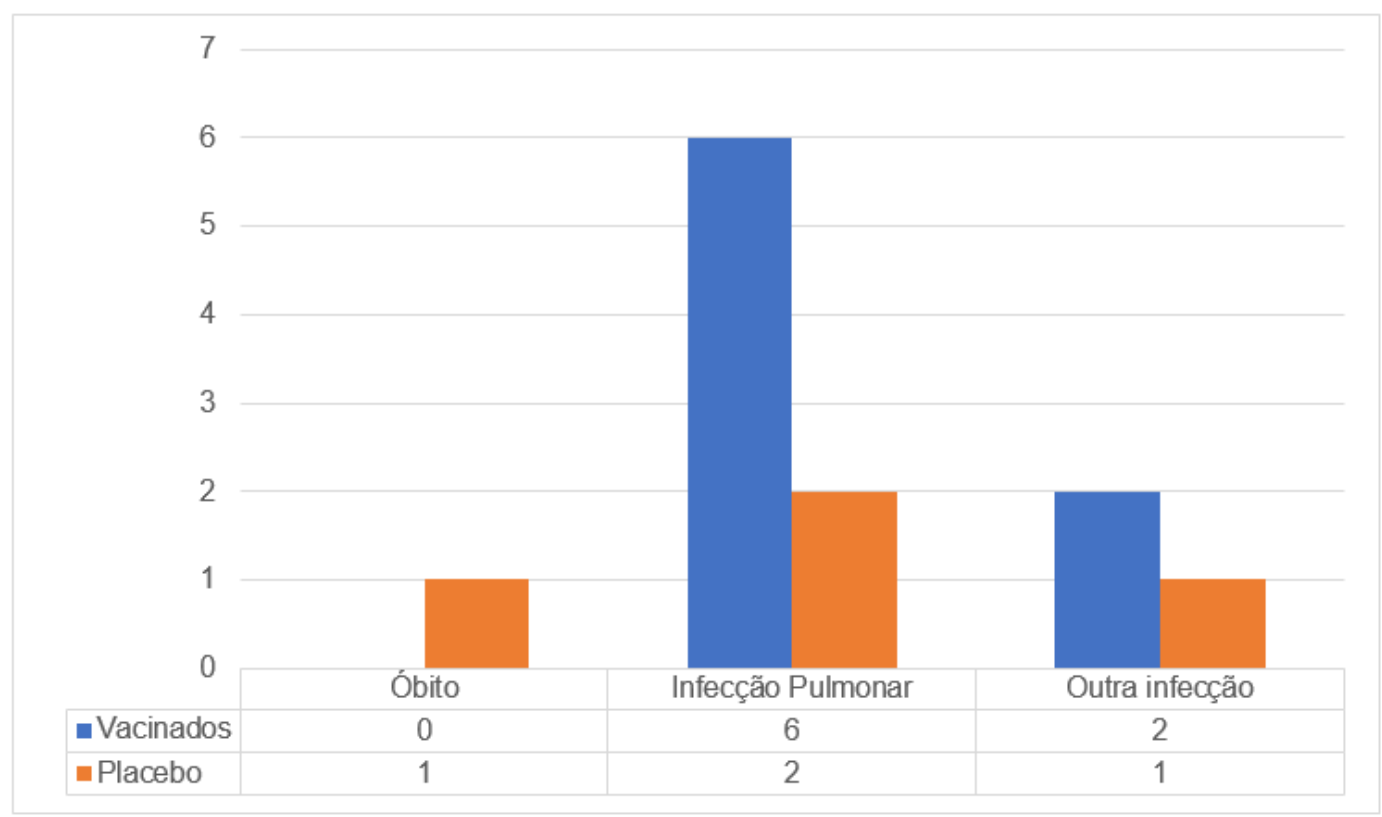

Source: Own authorship. 
Regarding the relative risks for the occurrence of deaths and infections, whether pulmonary or not, comparing the placebo and vaccine groups, none of the correlations was statistically significant. The results were described in Table 2.

Table 2 - Estimated relative risk of the occurrence of death and infections comparing placebo (not exposed) $\mathrm{x}$ vaccine (exposed).

\begin{tabular}{lccc}
\hline \multicolumn{1}{c}{ Variable } & Relative risk & CI (95\%) & P value \\
\hline Death & 0.333 & $0.1438-7.7244$ & $0.4933 *$ \\
\hline Pulmonary infection & 3.00 & $0.6860-13.1188$ & $0.1175 * *$ \\
\hline Another infection & 2.00 & $0.1967-20.3331$ & $0.5 * *$ \\
\hline
\end{tabular}

* Chi- square test

** Fischer test

Source: Own authorship.

In the comparison between the groups of patients who presented any type of infection with those who were not infected, it is worth mentioning the statistical significance found between the presence of infection and chronic obstructive pulmonary disease $(p=0.003)$, peripheral arterial disease $(p=0.0001)$ and diabetes mellitus $(p=0.0470)$. The other results were not statistically significant and are described in Table 3.

Table 3 - Absolute and relative frequency of each variable according to the groups that had or did not have infection.

\begin{tabular}{|c|c|c|c|c|}
\hline Variable & Categories & With Infection & No infection & Total \\
\hline \multirow[t]{3}{*}{ Age } & $\leq 65$ years & $4(18.2 \%)$ & $18(81.8 \%)$ & $22(55 \%)$ \\
\hline & $>65$ years & $7(38.9 \%)$ & $11(61.1 \%)$ & $18(45 \%)$ \\
\hline & & & & $\mathrm{P}=0.1351 *$ \\
\hline \multirow[t]{3}{*}{ Gender } & Male & $9(27.3 \%)$ & $24(72.7 \%)$ & $33(82.5 \%)$ \\
\hline & Female & $2(28.6 \%)$ & $5(71.4 \%)$ & $7(17.5 \%)$ \\
\hline & & & & $\mathrm{P}=0.6360 *$ \\
\hline \multirow[t]{2}{*}{ Mean Weight } & 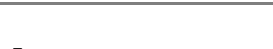 & 79.45 & 74.24 & 75.67 \\
\hline & - & & & $\mathrm{P}=0.4662 * * * *$ \\
\hline \multirow[t]{2}{*}{ Mean Height } & & 1.67 & 1.66 & 1.66 \\
\hline & - & & & $\mathrm{P}=0.7939 * * * *$ \\
\hline \multirow[t]{2}{*}{ Median Creatinine } & & 1.08 & 0.95 & 1.00 \\
\hline & - & & & $\mathrm{P}=0.3398 * * *$ \\
\hline \multirow[t]{5}{*}{ Renal Dysfunction } & No dysfunction & $6(37.5 \%)$ & $10(62.5 \%)$ & $16(40 \%)$ \\
\hline & Moderate & $4(20 \%)$ & $16(80 \%)$ & $20(50 \%)$ \\
\hline & Severe & $1(25 \%)$ & $3(75 \%)$ & $4(10 \%)$ \\
\hline & Dialysis & $0(0 \%)$ & $0(0 \%)$ & $0(0 \%)$ \\
\hline & & & & $\mathrm{P}=0.5017 * *$ \\
\hline \multirow[t]{3}{*}{ Diabetes } & With DM & $6(50 \%)$ & $6(50 \%)$ & $12(30 \%)$ \\
\hline & Without DM & $5(17.86 \%)$ & $23(82.14 \%)$ & $28(70 \%)$ \\
\hline & & & & $\mathrm{P}=0.0470 *$ \\
\hline \multirow[t]{3}{*}{ Insulin use } & Yes & $2(50 \%)$ & $2(50 \%)$ & $4(10 \%)$ \\
\hline & No & $9(25 \%)$ & $27(75 \%)$ & $36(90 \%)$ \\
\hline & & & & $\mathrm{P}=0.3 *$ \\
\hline \multirow[t]{5}{*}{ Peripheral Arterial Disease } & No & $6(17.1 \%)$ & $29(82.9 \%)$ & $35(87.5 \%)$ \\
\hline & Carotids & $5(100 \%)$ & $0(0 \%)$ & $5(12.5 \%)$ \\
\hline & Claudication & $0(0 \%)$ & $0(0 \%)$ & $0(0 \%)$ \\
\hline & $\begin{array}{l}\text { Abdominal Aortic } \\
\text { aneurysm }\end{array}$ & $0(0 \%)$ & $0(0 \%)$ & $0(0 \%)$ \\
\hline & & & & $\mathrm{P}=0.0001 * *$ \\
\hline \multirow[t]{3}{*}{ Previous cardiac surgery } & Yes & $2(40 \%)$ & $3(60 \%)$ & $5(12.5 \%)$ \\
\hline & No & $9(25.7 \%)$ & $26(74.3 \%)$ & $35(87.5 \%)$ \\
\hline & & & & $\mathrm{P}=0.4224 *$ \\
\hline Chronic Obstructive Pulmonary & Yes & $5(83.3 \%)$ & $1(16.7 \%)$ & $6(15 \%)$ \\
\hline
\end{tabular}


Research, Society and Development, v. 10, n. 4, e11410413982, 2021

(CC BY 4.0) | ISSN 2525-3409 | DOI: http://dx.doi.org/10.33448/rsd-v10i4.13982

\begin{tabular}{|c|c|c|c|c|}
\hline Disease & No & $6(17.6 \%)$ & $28(82.4 \%)$ & $\begin{array}{l}34(85 \%) \\
\mathrm{P}=0.003 *\end{array}$ \\
\hline NYHA Functional Class & $\begin{array}{l}\text { I } \\
\text { II } \\
\text { III } \\
\text { IV }\end{array}$ & $\begin{array}{l}2(28.6 \%) \\
4(25 \%) \\
4(36.4 \%) \\
1(16.7 \%)\end{array}$ & $\begin{array}{l}5(71.4 \%) \\
12(75 \%) \\
7(63.6 \%) \\
5(83.3 \%)\end{array}$ & $\begin{array}{l}7(17.5 \%) \\
16(40 \%) \\
11(27.5 \%) \\
6(15 \%) \\
P=0.8397 * *\end{array}$ \\
\hline Unstable Angina & $\begin{array}{l}\text { No } \\
\text { Yes }\end{array}$ & $\begin{array}{l}8(25.8 \%) \\
3(33.3 \%)\end{array}$ & $\begin{array}{l}23(74.2 \%) \\
6(66.7 \%)\end{array}$ & $\begin{array}{l}31(77.5 \%) \\
9(22.5 \%) \\
\mathrm{P}=0.4767 *\end{array}$ \\
\hline Mean Ejection Fraction & - & $60 \%$ & $56.1 \%$ & $\begin{array}{l}57.17 \% \\
\mathrm{P}=0.4447 * * * *\end{array}$ \\
\hline Recent AMI & $\begin{array}{l}\text { Yes } \\
\text { No }\end{array}$ & $\begin{array}{l}2(33.3 \%) \\
9(26.5 \%)\end{array}$ & $\begin{array}{l}4(66.7 \%) \\
25(73.5 \%)\end{array}$ & $\begin{array}{l}6(15 \%) \\
34(85 \%) \\
P=0.5359 *\end{array}$ \\
\hline Pulmonary hypertension & $\begin{array}{l}\text { Normal } \\
\text { Moderate } \\
\text { Severe }\end{array}$ & $\begin{array}{l}6(21.4 \%) \\
3(50 \%) \\
2(33.3 \%)\end{array}$ & $\begin{array}{l}22(78.6 \%) \\
3(50 \%) \\
4(66.7 \%)\end{array}$ & $\begin{array}{l}28(70 \%) \\
6(15 \%) \\
6(15 \%) \\
P=0.3424 * *\end{array}$ \\
\hline Surgery & $\begin{array}{l}\text { Coronary } \\
\text { Valve } \\
\text { Coronary and valve } \\
\text { Other }\end{array}$ & $\begin{array}{l}4(28.6 \%) \\
5(25 \%) \\
2(50 \%) \\
0(0 \%)\end{array}$ & $\begin{array}{l}10(71.4 \%) \\
15(75 \%) \\
2(50 \%) \\
2(100 \%)\end{array}$ & $\begin{array}{l}14(35 \%) \\
20(50 \%) \\
4(10 \%) \\
2(5 \%) \\
P=0.6052 * *\end{array}$ \\
\hline Aortic Surgery & $\begin{array}{l}\text { Yes } \\
\text { No }\end{array}$ & $\begin{array}{l}1(50 \%) \\
10(26.3 \%)\end{array}$ & $\begin{array}{l}1(50 \%) \\
28(73.7 \%)\end{array}$ & $\begin{array}{l}2(5 \%) \\
38(95 \%) \\
\mathrm{P}=0.4794 *\end{array}$ \\
\hline EuroSCORE II & $\begin{array}{l}\text { Low risk }(<2) \\
\text { Medium risk }(2-4) \\
\text { High risk }(4-6) \\
\text { Very high risk }(>6)\end{array}$ & $\begin{array}{l}4(18.2 \%) \\
2(33.3 \%) \\
2(40 \%) \\
3(42.9 \%)\end{array}$ & $\begin{array}{l}18(81.8 \%) \\
4(66.7 \%) \\
3(60 \%) \\
4(57.1 \%)\end{array}$ & $\begin{array}{l}22(55 \%) \\
6(15 \%) \\
5(12.5 \%) \\
7(17.5 \%) \\
P=0.5163 * *\end{array}$ \\
\hline $\begin{array}{l}\text { Median Cardiopulmonary } \\
\text { Bypass Time }\end{array}$ & - & 88 & 74 & $\begin{array}{l}74.5 \\
\mathrm{P}=0.4760 * * *\end{array}$ \\
\hline Median Aortic Clamping Time & - & 76 & 60 & $\begin{array}{l}63.5 \\
\mathrm{P}=0.686 * * *\end{array}$ \\
\hline Intensive Care Unit Time & $\begin{array}{l}\leq 4 \text { days } \\
>4 \text { days }\end{array}$ & $\begin{array}{l}5(15.6 \%) \\
6(75 \%)\end{array}$ & $\begin{array}{l}27(84.4 \%) \\
2(25 \%)\end{array}$ & $\begin{array}{l}32(80 \%) \\
8(20 \%) \\
P=0.0025 *\end{array}$ \\
\hline Postoperative length of stay & $\begin{array}{l}\leq 5 \text { days } \\
>5 \text { days }\end{array}$ & $\begin{array}{l}4(14.8 \%) \\
7(53.8 \%)\end{array}$ & $\begin{array}{l}23(85.2 \%) \\
6(46.2 \%)\end{array}$ & $\begin{array}{l}27(67.5 \%) \\
13(32.5 \%) \\
P=0.0147 *\end{array}$ \\
\hline Death & $\begin{array}{l}\text { Discharge } \\
\text { Death } \\
\text { Death after discharge }\end{array}$ & $\begin{array}{l}10(25.6 \%) \\
1(100 \%) \\
0(0 \%)\end{array}$ & $\begin{array}{l}29(74.4 \%) \\
0(0 \%) \\
0(0 \%)\end{array}$ & $\begin{array}{l}39(97.5 \%) \\
1(2.5 \%) \\
0(0 \%) \\
\mathrm{P}=0.1044 * *\end{array}$ \\
\hline Depression or Anxiety & $\begin{array}{l}\text { Yes } \\
\text { No }\end{array}$ & $\begin{array}{l}5(38.5 \%) \\
6(22.2 \%)\end{array}$ & $\begin{array}{l}8(61.5 \%) \\
21(77.8 \%)\end{array}$ & $\begin{array}{l}13(32.5 \%) \\
27(67.5 \%) \\
P=0.2394 *\end{array}$ \\
\hline Hypothyroidism & $\begin{array}{l}\text { Yes } \\
\text { No }\end{array}$ & $\begin{array}{l}1(25 \%) \\
10(27.8 \%)\end{array}$ & $\begin{array}{l}3(75 \%) \\
26(72.2 \%)\end{array}$ & $\begin{array}{l}4(10 \%) \\
36(90 \%) \\
P=0.6996 *\end{array}$ \\
\hline Systemic Arterial Hypertension & $\begin{array}{l}\text { Yes } \\
\text { No }\end{array}$ & $\begin{array}{l}8(25 \%) \\
3(37.5 \%)\end{array}$ & $\begin{array}{l}24(75 \%) \\
5(62.5 \%)\end{array}$ & $\begin{array}{l}32(80 \%) \\
8(20 \%) \\
P=0.3812 *\end{array}$ \\
\hline Dyslipidemia & $\begin{array}{l}\text { No } \\
\text { High LDL } \\
\text { Low HDL } \\
\text { Mixed }\end{array}$ & $\begin{array}{l}1(16.7 \%) \\
6(33.3 \%) \\
1(100 \%) \\
1(14.3 \%)\end{array}$ & $\begin{array}{l}5(83.3 \%) \\
12(66.7 \%) \\
0(0 \%) \\
6(85.7 \%)\end{array}$ & $\begin{array}{l}6(17.6 \%) \\
18(52.9 \%) \\
1(2.9 \%) \\
7(20.53 \%) \\
P=0.2409 * *\end{array}$ \\
\hline
\end{tabular}




\begin{tabular}{lllll}
\hline \multicolumn{5}{c}{} \\
Smoking & Yes & $4(40 \%)$ & $6(60 \%)$ & $10(25 \%)$ \\
& No & $3(18.7 \%)$ & $13(81.3 \%)$ & $16(40 \%)$ \\
& Ex-smoker & $4(28.6 \%)$ & $10(71.4 \%)$ & $14(35 \%)$ \\
& & & $\mathrm{P}=0.4951 * *$ \\
\hline Alcoholism & Yes & $0(0 \%)$ & $5(100 \%)$ & $5(12.5 \%)$ \\
& No & $10(33.3 \%)$ & $20(66.7 \%)$ & $30(75 \%)$ \\
& Ex-alcoholic & $1(20 \%)$ & $4(80 \%)$ & $5(12.5 \%)$ \\
& & & $\mathrm{P}=0.2795 * *$ \\
\hline
\end{tabular}

* Fischer test

** Chi Test - Square

*** Mann-Whitney test

$* * * *$ Student's T test

Source: Own authorship.

The relative risk between the presence of infections and the number of deaths, postoperative hospital stay and length of stay in the intensive care unit are shown in Table 4. There was a correlation between the development of postoperative infections and an increase in the length of hospital stay (95\% CI: $1.33-7.13 ; p=0.0147)$ and length of stay in the ICU $(95 \% \mathrm{CI}$ : 1.87- 33.45; $\mathrm{p}=0.0025)$.

Table 4 - Estimated relative risk of death, ICU length of stay and postoperative length of stay comparing patients with infection vs. without infection.

\begin{tabular}{llll}
\hline Variable & Relative risk & CI (95\%) & P value \\
\hline Death & 7.5 & $0.3279-171.53$ & $0.2070^{*}$ \\
\hline Postoperative Hospitalization Time & 3.0758 & $1.3264-7.1321$ & $0.0147^{* *}$ \\
\hline ICU time & 7.9091 & $1.8701-33.4487$ & $0.0025^{* *}$ \\
\hline
\end{tabular}

* Fischer test

* Chi-square test

Source: Own authorship.

\section{Discussion}

Hospital infections, which occur during hospitalization or up to 48-72 hours after the patient's discharge, are important causes of mortality and morbidity, in addition to increasing hospitalization costs and hospital stay (Damavandi et al., 2020). In this study, for example, it was found that the presence of infections increased the length of postoperative hospital stay (95\% CI: 1.33- 7.13; $\mathrm{p}=0.0147$ ) and the length of stay in the ICU (95\% CI: 1.87- 33.45; $\mathrm{p}=0.0025)$. According to Ailawadi et al. (2017), the additional cost caused by a hospital infection is 38 thousand dollars, being 29.692 dollars in the case of pneumonia, which increase the length of hospital stay by 10 days.

In the world, about 600 thousand patients need to undergo cardiac surgery annually and, in these cases, there is a greater susceptibility mainly to the development of pneumonia, which, among the infections acquired after cardiac procedures, is the main and the one with the highest index of mortality, occurring in 2 to $13 \%$ of patients (Vera Urquiza et al., 2016; Damavandi et al., 2020). In research by Ortiz et al. (2010) with 202 patients undergoing myocardial revascularization, for example, 20 (9.9\%) had pneumonia. It is also worth mentioning that nosocomial infections are more resistant to antimicrobials, which increases the complexity of treatment and the frequency of refractory pneumonia (Topal \& Eren, 2012).

The high incidence of pneumonia in the postoperative period of cardiac surgery can be explained by the fact that many of the patients who need these procedures already have several risk factors, such as COPD, heart failure and old age. In addition, the use of cardiopulmonary bypass causes inflammatory effects and has the potential to cause lung damage. Even the 
pain generated by sternotomy and thoracotomy can alter respiratory dynamics and predispose patients to respiratory infections (Ailawadi et al., 2017).

In this research, it was possible to list as risk factors for the development of postoperative infections, peripheral arterial disease $(\mathrm{p}=0.0001)$, chronic obstructive pulmonary disease $(\mathrm{p}=0.003)$ and DM $(\mathrm{p}=0.047)$. In the study by Vera Urquiza et al. (2016), the main associated factors were the need for reintubation and chronic renal failure, in addition to the time of intubation, in which patients who remained intubated for more than 48 hours presented pneumonia in $45.1 \%$ of cases.

In a study conducted by Sheng et al. (2014), who associated all independent variables with the need for mechanical ventilation in patients undergoing major cardiac surgery, concluded that the main factors associated with the development of pneumonia were: age, Euroscore, time of bypass, need for blood transfusion, need for reintubation, reoperation and days spent on mechanical ventilation. Finally, in a study by Strobel et al. (2020), the preoperative risk of developing pneumonia was higher in patients with chronic liver disease, need for oxygen therapy, smokers, patients with COPD or a history of previous pneumonia. In addition, this study also proved that pneumonia caused an increase in the length of stay in the ICU.

In the present study, although the same variables as in the studies mentioned above were tested, the association between them was not significant in the development of respiratory infections, except in the case of COPD ( $\mathrm{p}=0.003$ ), DM $(\mathrm{p}=0.047)$ and arterial peripheral disease $(\mathrm{p}=0.0001)$. The mean age, which was determined as a risk factor by Sheng et al. (2014), for example, presented a $\mathrm{p}=0.135$. The use of insulin $(\mathrm{p}=0.3)$, presence of previous cardiac surgery $(\mathrm{p}=0.4224)$, unstable angina $(\mathrm{p}=0.4767)$, recent AMI $(\mathrm{p}=0.5359)$, aortic surgery $(\mathrm{p}=0.4794)$, depression or anxiety $(\mathrm{p}=0.2394)$, hypothyroidism $\quad(\mathrm{p}=0.6996), \quad \mathrm{SAH} \quad(\mathrm{p}=0.3812)$, renal dysfunction $\quad(\mathrm{p}=0$. 5017) aortic clamping time $(\mathrm{p}=0.686)$ and cardiopulmonary bypass time $(\mathrm{p}=0.4760)$ were also not relevant as risk factors.

In other studies, the presence of pneumonia resulted in an increase in mortality, which reached 8-9 times higher, with mortality rates after 65 days of 6\% (Ailawadi et al., 2017). However, in this study, the presence of infection did not increase mortality (95\% CI: $0.33-171.5 ; \mathrm{p}=0.207$ ).

In this context, the main agent responsible for the development of pneumonia, whether hospital-acquired or acquired in the community, is Streptococcus pneumoniae, known as pneumococcus (Lanks, Musani \& Hsia, 2019). The 13v pneumococcal vaccine aims to prevent $90 \%$ of infections caused by 13 pneumococcal serotypes and has already been studied for other outcomes, such as preventing exacerbations in COPD patients, showing results mainly in patients with concomitant cardiovascular disease (Figueira Gonçalves, García Bello, Bethencourt Martín, Díaz Pérez \& Pérez-Méndez, 2019; SBIM, 2020). There is also a vaccination recommendation for patients who will undergo heart transplants (Sarmiento et al., 2006). However, no articles were found that reported the use of this vaccine in order to prevent respiratory infections in the postoperative period of other cardiac surgeries.

This study, in turn, sought to clarify this purpose, which has not yet been researched. However, no statistically significant correlation was found between the variable vaccine and infections, whether pulmonary (95\% CI: 0.69-13.12; $\mathrm{p}=$ $0.1444)$ or not (95\% CI: $0.17-20.33 ; \mathrm{p}=0.5580)$. There was also no significant relationship between vaccination and the number of deaths (95\% CI: 0.14-7.72; $\mathrm{p}=0.4933)$.

This research, however, presented a very small sample as a limitation. This is justified by the need to apply the vaccines 14 days before the procedure, which, therefore, needed to be elective. However, with the emergence of SARS-CoV-2, most of these surgeries were canceled, with only urgent surgeries being performed. Another limitation is the fact that this study is single-centered. Nevertheless, in this research, all the main variables identified as preoperative risk factors for the development of respiratory infections in the postoperative period were addressed, with samples from homogeneous patients. 


\section{Conclusion}

In this series, 6 pulmonary infections occurred in the vaccine group (30\%) and 2 in the placebo group (10\%) and another type of infection occurred in 2 patients in the vaccine group (10\%) and in 1 patient in the placebo group (5\%). There was only one death in the placebo group (5\%), similar to that observed in the literature.

Immunization with the pneumococcal $13 \mathrm{v}$ vaccine did not reduce the occurrence of infections in the postoperative period of cardiac surgery compared to the placebo group.

Peripheral arterial disease, diabetes mellitus and chronic obstructive pulmonary disease were risk factors for the development of infections in the postoperative period of cardiac surgery.

The presence of infections did not increase mortality, but it did increase the length of postoperative hospital stay and the length of stay in the ICU.

Due to the limitations in this study, we encourage future studies in this area, collecting data from more patients, preferably in a multicentred research.

\section{References}

Ailawadi, G., Chang, H. L., Gara, P. T. O., Karen, O., Woo, Y. J., Jr, J. J. D., Parides, M. K., Vinod, H., Robichaud, S., Gillinov, A. M., Taddei-peters, W. C., Miller, M. A., Perrault, L. P., Smith, R. L., Horvath, K. A., Doud, K., Baio, K., \& Annetine, C. (2017). Pneumonia After Cardiac Surgery: Experience of the NIH/CIHR Cardiothoracic Surgical Trials Network. J Thorac Cardiovasc Surg, 153(6), 1384-1391.

Bonten, M. J. M., Huijts, S. M., Bolkenbaas, M., Webber, C., Patterson, S., Gault, S., van Werkhoven, C. H., van Deursen, A. M. M., Sanders, E. A. M., Verheij, T. J. M., Patton, M., McDonough, A., Moradoghli-Haftvani, A., Smith, H., Mellelieu, T., Pride, M. W., Crowther, G., Schmoele-Thoma, B., Scott, D. A., \& Grobbee, D. E. (2015). Polysaccharide Conjugate Vaccine against Pneumococcal Pneumonia in Adults. New England Journal of Medicine, 372(12), $1114-1125$

Damavandi, D. S., Javan, M., Moshashaei, H., Forootan, M., \& Darvishi, M. (2020). Microbial Contamination after Cardiac Surgery in a Hospital Cardiac Surgery Ward. Journal of Medicine and Life, 13(3), 342-348.

Dordetto, P. R., Pinto, G. C., \& Rosa, T. C. S. de C. (2016). Pacientes submetidos à cirurgia cardíaca: caracterização sociodemográfica, perfil clínico-epidemiológico e complicações. Revista Da Faculdade de Ciências Médicas de Sorocaba, 18(3), 144-149.

Figueira Gonçalves, J. M., García Bello, M. A., Bethencourt Martín, N., Díaz Pérez, D., \& Pérez-Méndez, L. I. (2019). Impact of 13-valent pneumococcal conjugate polysaccharide vaccination on severe exacerbations in patients with chronic obstructive pulmonary disease and established cardiovascular disease. European Journal of Internal Medicine, 63(February), e14-e16.

Lanks, C. W., Musani, A. I., \& Hsia, D. W. (2019). Community-acquired Pneumonia and Hospital-acquired Pneumonia. Medical Clinics of North America, $103(3), 487-501$.

Lentsck, M. H., Latorre, M. do R. D. de O., \& Mathias, T. A. de F. (2015). Tendência das internações por doenças cardiovasculares sensíveis à atenção primária. Revista Brasileira de Epidemiologia, 18(2), 372-384.

Ministério da Saúde Brasil (2019). Departamento de Informática do SUS - DATASUS. Informações de Saúde, Mortalidade Geral. http://www2.datasus.gov.br/DATASUS/index.php?area=0205\&id=6937\&VObj=http://tabnet.datasus.gov.br/cgi/deftohtm.exe?sim/cnv/obt10

Nashef, S. A. M., Roques, F., Sharples, L. D., Nilsson, J., Smith, C., Goldstone, A. R., \& Lockowandt, U. (2012). Euroscore II. European Journal of CardioThoracic Surgery, 41(4), 734-745.

Ortiz, L. D. N., Schaan, C. W., Leguisamo, C. P., Tremarin, K., Mattos, W. L. L. D., Kalil, R. A. K., \& Pellanda, L. C. (2010). Incidence of pulmonary complications in myocardial revascularization. Arquivos Brasileiros de Cardiologia, 95(4), 441-446.

Pereira A. S. et al. (2018). Metodologia da pesquisa científica. UFSM. https://repositorio.ufsm.br/bitstream/handle/1/15824/Lic_Computacao_Metodolo gia Pesquisa -Cientifica.pdf?sequence $=1$

Sarmiento, E., Rodríguez-Hernández, C., Rodríguez-Molina, J., Fernández-Yánez, J., Palomo, J., Anguita, J., Pérez, J. L., Lanio, N., Fernández-Cruz, E., \& Carbone, J. (2006). Impaired anti-pneumococcal polysaccharide antibody production and invasive pneumococcal infection following heart transplantation. International Immunopharmacology, 6(13-14), 2027-2030.

Strobel, R. J., Harrington, S. D., Hill, C., Thompson, M. P., Cabrera, L., Theurer, P., Wilton, P., Gandhi, D., Delucia Iii, A., Paone, G., Wu, X., Zhang, M., Krein, S. L., Prager, R. L., \& Likosky, D. S. (n.d.). Evaluating The Impact of Pneumonia Prevention Recommendations Following Cardiac Surgery on behalf 
Research, Society and Development, v. 10, n. 4, e11410413982, 2021

(CC BY 4.0) | ISSN 2525-3409 | DOI: http://dx.doi.org/10.33448/rsd-v10i4.13982

of the Michigan Society of Thoracic and Cardiovascular Surgeons Quality Collaborative, 110(3), 903-910.

SBIM - Sociedade Brasileira de Imunizações (2020). Doença Pneumocócica. https://familia.sbim.org.br/doencas/doenca-pneumococica-dp

Sheng, W., Xing, Q. S., Hou, W. M., Sun, L., Niu, Z. Z., Lin, M. S., \& Chi, Y. F. (2014). Independent risk factors for ventilator-associated pneumonia after cardiac surgery. Journal of Investigative Surgery, 27(5), 256-261.

Topal, A. E., \& Eren, M. N. (2012). Risk factors for the development of pneumonia post cardiac surgery. Cardiovascular Journal of Africa, 23(4), 212-215.

Vera Urquiza, R., Bucio Reta, E. R., Berríos Bárcenas, E. A., \& Choreño Machain, T. (2016). Factores de riesgo para desarrollar neumonía postquirúrgica en pacientes operados de cirugía cardiaca. Archivos de Cardiologia de Mexico, 86(3), 203-207. 